\title{
EFEKTIVITAS PEMBERIAN TEKNIK MASSAGE EFFLEURAGE DAN TEKNIK MASSAGE CONTERPRESSURE TERHADAP RASA NYERI PERSALINAN NORMAL PADA PRIMIGRAVIDA DI LANGSA TAHUN 2017
}

\author{
Ellysusilawati ${ }^{1)}$ \\ E-mail address: ellysusilawatiramli@gmail.com
}

\begin{abstract}
Labor pain is a manifestation of contractions of the uterine muscles. Pain in childbirth if left untreated will increase anxiety, tensionand stress. Increased consumption of body glucose in maternity mothers who experience stress causes fatigue and catecholamine secretion that inhibits uterine contractions, which causes prolonged labor which ultimately causes anxiety in the mother, increased pain and prolonged stress. Massage can be used during labor and may be an effective pain reliever. The common massage technique is effleurage and Conterpressure.

The aim this studyto determine the effectiveness of providing Effleurage Massage and Conterpressure Massage techniques in Active Phase Pain Reduction during normal labor in Primigravida mother at Eva Repelitamidwifery practice and Rusmalanitamidwifery practice Langsa City. Design of this study was quasi experimental design with posttest only control group design in the form of pain scaling in the first stage of active labor, conducted at Eva Repelita, Am.Keb midwifery practice and Rusmalanita Am.Keb midwifery practice in February to April 2017 Langsa City. The sample in this study were mothers, whom divided into two groups numbered 16 people, thus the total sample was 32 people. Data analysis techniques used are Univariate and Bivariate analysis using Paired T-Test

The result of this study the mean pain scale in active phase of normal labor in Primigravida mothers, with Effleurage Massage Technique was 2 with SD 2.44 deviation, while the mean pain scale with Massage Conterpressure technique is 6 with SD 6.36 deviation. While the results of the Statistical Test using Paired T-test obtained $\mathrm{P}$ value of 0,000 , that the Effleurage Massage technique was more effective than the Conterpressure Massage technique in reducing labor pain during active phase. Conclusions: It can be concluded that Effleurage Massage technique was more effective than Conterpressure Massage technique in reducing labor pain during the active phase.
\end{abstract}

Keywords: Massage Effleurage; Massage Conterpressure; Labor pain

${ }^{1)}$ Poltekkes Kemenkes Riau

\section{Pendahuluan}

Kemajuan persalinan pada kala I fase aktif merupakan saat yang paling melelahkan, berat, dan kebanyakan ibu mulai merasakan sakit atau nyeri, dalam fase ini kebanyakan ibu merasakan sakit yang hebat karena kegiatan rahim mulai lebih aktif. Pada fase ini kontraksi semakin lama, semakin kuat, dan semakin sering yang dapat menimbulkan kecemasan. Kecemasan pada ibu bersalin kala I 
bisa berdampak meningkatnya sekresi adrenalin. Salah satu efek adrenalin adalah kontraksi pembuluh darah sehingga suplai oksigen ke janin menurun. Penurunan aliran darah juga menyebabkan melemahnya kontraksi rahim dan berakibat memanjangnya proses persalinan hingga dapat menyebabkan persalinan lama.Dalam hal ini peranan petugas kesehatan tidak kalah penting dalam memberikan bantuan dan dukungan pada ibu agar seluruh rangkaian proses persalinan berlangsung dengan aman baik bagi ibu maupun bagi bayi yang dilahirkan (Sumarah, 2009).

Nyeri pada persalinan apabila tidak diatasi maka akan meningkatkan rasa khawatir, tegang, takut dan stress. Peningkatan konsumsi glukosa tubuh pada ibu bersalin yang mengalami stress menyebabkan kelelahan dan sekresi katekolamin yang menghambat kontraksi uterus, hal tersebut menyebabkan persalinan lama yang akhirnya menyebabkan cemas pada ibu, peningkatan nyeri dan stress berkepanjangan. Massage (pijatan) dapat digunakan selama persalinan dan mungkin merupakan tindakan pereda nyeri yang efektif. Teknik massage yang umum dilakukan adalah effleurage (bentuk massage dengan menggunakan telapak tangan yang memberi tekanan lembut ke atas permukaan tubuh dengan arah sirkular secara berulang)danConterpressure (teknik pijatan kuat dengan cara meletakkan tumit tangan atau juga menggunakan bola tennis, tekanan dapat diberikan dalam gerakan lurus atau lingkaran kecil). Menggosok bagian tubuh apapun, bahkan diantara kontraksi, mungkin dapat berperan untuk meredakan nyeri. Ini tidak hanya mendorong relaksasi, tetapi percobaan dengan stimulasi kutaneus memperlihatkan bahwa tindakan ini dapat bermanfaat dalam waktu lama setelah penggunaannya(Reader, 2001).

Peranan Massage Effleurage dan Conterpressure Stimulasi kulit dengan kedua teknik ini menghasilkan impuls yang di kirim lewat serabut saraf besar yang berada dipermukaan kulit, serabut saraf besar ini akan menutup gerbang pesan nyeri sehingga otak tidak menerima pesan nyeri karena sudah di blokir oleh stimulasi kulit dan dengan kedua teknik massage ini dapat mengaktifkan senyawa endhorpin yang berada di sinaps sel-sel saraf tulang belakang dan otak, sehingga tranmisi dari pesan nyeri dapat dihambat, akibatnya persepsi nyeri akan berubah. Selain meredakan nyeri, teknik ini juga dapat mengurangi ketegangan otot dan meningkatkan sirkulasi darah diarea yang terasa nyeri(Yuliatun, 2008)

Upaya-upaya

untukmenanggulangi nyeri pada persalinan telah dilakukan berbagai cara nonfarmakologis dan farmakologis. Metode nonfarmakologis antara lain distraksi, teknik relaksasi, hipnotis, serta mengurangi persepsi nyeri dan farmakologis yaitu dengan penggunaan obat analgetik. Pengendalian nonfarmakologis lebih murah, simpel, efektif dan tanpa efek merugikan. Metode ini juga dapat meningkatkan kepuasan selama persalinan karena ibu dapat mengontrol perasaan dan kekuatannya (Asmadi, 2009). Bersamaan dengan nyeri persalinan yang dirasakan oleh ibu-ibu yang akan bersalin dilakukan berbagai cara untuk menanggulangi nyeri pada persalinan yaitu salah satunya dengan menggunakan teknik massage pada 
punggung bawah, sehingga peneliti tertarik untuk melakukan penelitian tentang bagaimana gambaran pemberian massageterhadap pengurangan nyeri persalinan normal kala 1 fase aktif(Asmadi, 2009).

\section{Metode Penelitian}

Rancangan penelitian ini adalah quasi experimental design dengan the posttest only control group design. Penelitian dilaksanakandi BPM Eva Repelita, Am.Keb dan BPM Rusmalanita Am.Keb pada bulan Februari s/d April tahun 2017 Kota Langsa.Sampel penelitian ini adalah Ibu bersalin berjumlah 32 orang yang dibagi dalam 2 kelompok perlakuan : Dilakukan pemberian teknik massage effleurageselama 20 menitdan dilakukan di BPM Eva Repelita, Am.KebKota Langsa, kontrol : Dilakukan pemberian teknik massage Conterpressureselama 20 menitdi BPM Rusmalanita, Am.KebKota Langsa.

Teknik analisa data yang digunakan adalah : uji statistik dengan SPSS untuk mencari efektivitas pemberian teknik massage effleurage dan massage conterpressure terhadap pengurangan rasa nyeri persalinan normal kala I fase aktif pada ibu primigravida. Adapun uji yang akan digunakan adalah :Analisis univariat dan analisis bivariate menggunakan uji paired t-test.

\section{Hasil dan Pembahasan}

Tabel 1. Distribusi Frekuensi Responden Kelompok Perlakuan Teknik Massage Effleurage Untuk Pengurangan Rasa Nyeri Persalinan Normal Kala I fase Aktif Pada Ibu
Primigravida di BPM Eva Repelita, Am.Keb

\begin{tabular}{llcl}
\hline No & $\begin{array}{l}\text { Perlakuan Teknik } \\
\text { Massage Effleurage } \\
\text { Untuk Pengurangan } \\
\text { Rasa Nyeri Persalinan } \\
\text { Normal Kala I fase } \\
\text { Aktif }\end{array}$ & F & \\
& & \\
\hline 1 & 1 & 4 & 25 \\
2 & 2 & 5 & 31,3 \\
3 & 3 & 4 & 25 \\
4 & 4 & 2 & 12,5 \\
5 & 5 & 1 & 3,6 \\
\hline & total & 16 & 100 \\
\hline
\end{tabular}

Pengurangan rasa nyeri persalinan normal kala I fase aktif dengan teknik massage effleurage,mayoritasibu merasakan nyeri persalinandengan skala nyeriberada di grade 2 sebanyak ( $31,3 \%$ ) responden.

Tabel 2. Distribusi Frekuensi Responden Kelompok Kontrol Teknik Massage Conterpressure Untuk Pengurangan Rasa Nyeri Persalinan Normal Kala I fase Aktif Pada Ibu Primigravida di BPM Rusmalanita Am.Keb

\begin{tabular}{llcc}
\hline No & $\begin{array}{l}\text { Perlakuan Teknik } \\
\text { Massage Effleurage } \\
\text { Untuk Pengurangan } \\
\text { Rasa Nyeri }\end{array}$ & F & $\%$ \\
& & \\
& Persalinan Normal & & \\
& Kala I fase Aktif & & \\
\hline 1 & 5 & 2 & 12,5 \\
2 & 6 & 7 & 43,8 \\
3 & 7 & 6 & 37,5 \\
4 & 8 & 1 & 6,3 \\
\hline & total & 16 & 100 \\
\hline
\end{tabular}

Pengurangan rasa nyeri persalinan normal kala I fase aktif dengan teknik massage Conterpressure, mayoritas ibu merasakan nyeri persalinan dengan skala nyeri berada pada grade 6 sebanyak $(43,8 \%)$ responden. 
Tabel 3. HubunganEfektivitas Pemberian Teknik Massage Effleurage dan Massage Conterpressure Terhadap Pengurangan Rasa Nyeri Persalinan Normal Kala I fase Aktif Pada Ibu Primigravida di BPM Eva Repelita, Am.Keb dan BPM Rusmalanita Am.Keb Kota Langsa Tahun 2017

\begin{tabular}{|c|c|c|c|}
\hline $\begin{array}{c}\text { Karaktristik } \\
\text { (Variabel ) }\end{array}$ & Mean & SD & $\mathbf{P}_{\text {value }}$ \\
\hline \\
\hline \multicolumn{4}{|l|}{ Pengurangan } \\
\hline \multicolumn{4}{|l|}{ Rasa Nyeri } \\
\hline \multicolumn{4}{|l|}{ - Teknik } \\
\hline \multirow{2}{*}{\multicolumn{4}{|c|}{$\begin{array}{l}\text { Massage } \\
\text { Effleurage }\end{array}$}} \\
\hline & & & \\
\hline - Teknik & 6,36 & 0,806 & $\mathrm{~N}=16$ \\
\hline \multicolumn{4}{|l|}{ Massage } \\
\hline $\begin{array}{l}\text { Conterpressu } \\
\text { re }\end{array}$ & & & \\
\hline
\end{tabular}

Berdasarkan tabel 3, dari 16 responden (Teknik Massage Effleurage dan Massage Conterpressure) yang terdapat di BPM Eva Repelita, Am.Keb dan BPM Rusmalanita Am.Keb Kota Langsa menunjukkan rata-rata skala nyeri persalinan normal fase aktif pada ibu Primigravida, dengan Teknik Massage Effleurage adalah 2 dengan Std. deviasi 2,44, sedangkan rata-rata skala nyeri persalinan dengan Massage Conterpressure adalah 6 dengan Std. deviasi 6,36. Sedangkan hasil Uji Statistik mengunakan Paired T-test didapatkan nilai $\mathrm{P}$ value 0,000 maka bahwa tehnik Massage Effleurage lebih efektif dari pada tehnik Massage Conterpressure dalam mengurangi nyeri persalinan normal kala I fase aktif.

Massage (pijatan) cara lembut membantu ibu merasa lebih segar, rileks, dan nyaman selama persalinan, sebuah penelitian menyebutkan, ibu yang dipijat 20 menit setiap jam selama tahapan persalinan akan lebih bebas dari rasa sakit. Hal itu terjadi karena pijat merangsang tubuh melepaskan endorphin yang merupakan pereda sakit alami. Endorphin juga dapat menciptakan perasaan nyaman dan enak. Dalam persalinan, pijat juga membuat ibu merasa lebih dekat dengan orang yang merawatnya. Sentuhan seseorang yang peduli dan ingin menolong merupakan sumber kekuatan saat ibu sakit, lelah, dan kuat. Banyak bagian tubuhibu bersalin yang dapat dipijat, seperti kepala, leher, punggung, dan tungkai. Saat memijat, pemijat harus memerhatikan respons ibu, apakah tekanan yang diberikan sudah tepat (Yuliatun, 2008).

Teknik Effleurage Merupakan teknik pijatan dengan menggunakan telapak jari tangan dengan pola gerakan melingkar pada pinggang bagian bawah. Teknik effleurage massagediatas dapat menurunkan nyeripersalinan kala 1 fase aktif bila dilakukan dengan benar, yaitu dilakukan setiap adanya kontraksi dan dilakukan selama \pm 20 menit. Ibu bersalin mengatakan bahwa nyeri pada pinggang bagian bawah berkurang setelah dilakukan pijatan tersebut.

Penelitian ini tidak senada dengan penelitian yang dilakukan oleh Faradilah dengan judul efektifitas pemberian Effleurage dan Abdominal Lifting dengan relaksasi nafas dalam terhadap penurunan nyeri persalinan kala I di Klinik Bidan Indriani Semarang. Penelitian ini menggunakan desain quasi eksperimental dengan pretest-posttest design. Sampel pada penelitian ini adalah ibu bersalin di Klinik Bidan Indri Semarang yang ditetapkan secara purposive random sampling. Hasil analisis uji statistic 
dengan menggunakan uji MannWhitney didapatkan hasil untuk nilai $\rho$ $=0,031<\alpha 0,05$. Artinya kedua upaya penurunan nyeri tersebut sama- sama efektif untuk menurunkan nyeri persalinan kala I tetapi diantara keduanya lebih efektif relaksasi nafas dalam dibandingkan Effleurage dan Abdominal Lifting dengan hasil mean 4,85> 4,30 (Noor, 2013).

Penelitian ini tidak sejalan dengan penelitian yang dilakukan oleh Wardani dan Herlina dengan judul efektifitas masase effleurage dan masase counterpressure terhadap penurunan nyeri persalinan. Rancangan penelitian ini menggunakan quasi eksperiment dengan rancangan pre test - post test kontrol group design. Pengukuran dilakukan pada dua kelompok yaitu kelompok kontrol dan kelompok intervensi. Penelitian ini dilakukan di BPM yang masuk wilayah kerja Desa Sooko Kabupaten Mojokerto. Dari hasil uji t-test dengan tingkat kemaknaan $\alpha=0,05$ didapatkan nilai signifikasi sebesar 0,078 dengan nilai korelasi sebesar 0,487 yang berarti terapi massage effleurage tidak efektif untuk meredakan nyeri persalinan. Dari hasil uji ttest dengan tingkat kemaknaan $\alpha=0,05$ didapatkan nilai signifikasi sebesar 0,023 dengan nilai korelasi sebesar 0,602 yang berarti terapi massage counterpressure efektif untuk meredakan nyeri persalinan. Terapi massase counterpressure (sig : 0,001) lebih efektif digunakan sebagai terapi nonfarmakologis untuk meredakan nyeri persalinan dibandingkan dengan terapi massase effleurage (sig : 0,003).

\section{Simpulan}

Berdasarkan analisis bivariat dari 16 responden (Teknik Massage Effleurage dan Massage
Conterpressure) yang terdapat di BPM Eva Repelita, Am.Keb dan BPM Rusmalanita Am.Keb Kota Langsa menunjukkanrata-rata skala nyeri persalinan normal fase aktif pada ibu Primigravida, dengan Teknik Massage Effleurage adalah 2 dengan Std. deviasi 2,44, sedangkan rata-rata skala nyeri persalinan dengan Massage Conterpressure adalah 6 dengan Std. deviasi 6,36. Sedangkan hasil Uji Statistik mengunakan Paired T-test didapatkan nilai $\mathrm{P}$ value 0,000 maka dapat disimpulkan bahwa tehnik Massage Effleurage lebih efektif dari pada tehnik Massage Conterpressure dalam mengurangi nyeri persalinan normal kala I fase aktif

Diharapkan penelitian ini sebagai bahan masukan bagi pelayanan kebidanan(bidan) untuk dapat menerapkan terapi nonfarmakologis untuk mengatasi nyeri persalinan. Dikarenakan secara tidak langsung akan membantu ibu bersalin dalam mengatasi nyeri persalinan dan menekan terjadinya resiko komplikasi akibat persalinan yang terjadi.

\section{Daftar Pustaka}

Asmadi. 2009. Konsep danAplikasi Kebutuhan Dasar Klien, jil.1Jakarta : Salemba Medika

Asrinah, Putri, Sulistyorini, Muflihah, Sari, 2010. Asuhan Kebidanan Masa Persalinan. Graha Ilmu, yogyakarta.

Depkes RI. 2008. Asuhan Persalinan Normal, JNPK-KR, Jakarta. 
Perry dan Potter. 2006. Fundamental Keperawatan, Edisi 4, EGC, Jakarta

Noor, Faradilah Dhina. 2013. efektifitas pemberian Effleurage dan Abdominal Lifting dengan relaksasi nafas dalam terhadap penurunan nyeri persalinan kala I di Klinik Bidan Indriani Semarang. FIKKes Jurnal $\begin{array}{lll}\text { Keperawatan. } & \text { Vol.7 } & \text { No.2 }\end{array}$ Oktober 2014.

Sumarah, Yani Wiayastuti, Nining Wiyati. 2009. Perawatan Ibu Bersalin, Cetakan 4, Fitra Maya, Yogyakarta.

Walsh, Linda V. 2008. Buku Ajar Kebidanan Komunitas, Cetekan 1, EGC, Jakarta.

Wardani R.A dan Herlina. Efektifitas Masase Effleurage Dan Masase Counterpressure Terhadap Penurunan Nyeri Persalinan. Jurnal Keperawatan dan Kebidanan.

Yuliatun, Laily. (2008) Penanganan Nyeri Persalinan Dengan Metode Nonfarkologi. 